\title{
STRUCTURAL AND SPECTROSCOPIC CHARACTERIZATION OF $N^{\prime}$-[(1E)-(4-FLUOROPHENYL)METHYLIDENE]THIOPHENE-2-CARBOHYDRAZIDE, A POTENTIAL PRECURSOR TO BIOACTIVE AGENTS
}

\author{
Monirah A. Al-Alshaikh ${ }^{1}$, S. Muthu ${ }^{2}$, Ebtehal S. Al-Abdullah ${ }^{3}$, E. Elamurugu Porchelvi ${ }^{4}$, \\ Siham Lahsasni ${ }^{1}$, Ali A. El-Emam ${ }^{3 *}$ \\ ${ }^{1}$ Department of Chemistry, College of Sciences, King Saud University, Riyadh 11451, Saudi Arabia \\ ${ }^{2}$ Department of Physics, Sri Venkateshwara College of Engineering, Sriperumbudur 602105, \\ Tamil Nadu, India \\ ${ }^{3}$ Department of Pharmaceutical Chemistry, College of Pharmacy, King Saud University, \\ Riyadh 11451, Saudi Arabia \\ ${ }^{4}$ Department of Physics, Kanchi Pallavan Engineering College, Kanchipram-631502, Tamil Nadu, India \\ *elemam5@hotmail.com
}

In this study, vibrational spectral analysis of the title compound was carried out using FT-IR and FT-Raman spectroscopy in the range of $500-4000 \mathrm{~cm}^{-1}$. The vibrational analysis was aided by an electronic structure calculation based on the B3LYP/6-311++G(d,p) basis set. The molecular equilibrium geometries, IR and Raman intensities and harmonic vibrational frequencies were computed. The assignments were based on the experimental IR and Raman spectra, and a complete assignment of the observed spectra was proposed. The complete vibrational assignments were performed based on the potential energy distribution (PED). The thermodynamic properties of the title compound were calculated at different temperatures, revealing the correlations between heat capacity $(C)$, entropy $(S)$ and enthalpy changes $(H)$ with temperatures. In addition, the first-order hyperpolarizability, NBO, HOMO and LUMO energies, Fukui function and the molecular electrostatic potential were computed.

Keywords: DFT; FT-IR spectra; FT-Raman spectra; Fukui function;

$N^{\prime}$-(arylmethylidene)-thiophene-2-carbohydrazide

\section{СТРУКТУРНА И СПЕКТРОСКОПСКА КАРАКТЕРИЗАЦИЈА НА $N^{\prime}$-[(1E)-(4-ФЛУОРОФЕНИЛ)МЕТИЛИДЕН]ТИОФЕН-2-КАРБОХИДРАЗИД, ПОТЕНЦЈАЛЕН ПРЕКУРЗОР НА БИОАКТИВНИ СРЕДСТВА}

Во оваа студија е извршена вибрациона спектрална анализа на наведеното соединение со помош на FT-IR и FT-раманската спектроскопија во опсегот од 500-4000 $\mathrm{cm}^{-1}$. Вибрационата анализа беше помогната со пресметка на електронската структура базирана на B3LYP/6$311++\mathrm{G}(\mathrm{d}, \mathrm{p})$ како основен сет. Пресметани се молекулските рамнотежни геометрии, IR и раманските интензитети и хармониските вибрациони фреквенции. Асигнирањето е засновано врз експерименталните IR и рамански спектри и е предложена целосна асигнација на добиените спектри. Комплетните вибрациони асигнации се извршени врз основа на распределбата на потенцијалната енергија (PED). Термодинамичките својства на наведеното соединение се пресметани на различни температури, со што е добиена корелацијата меѓу топлинскиот капацитет $(C)$, ентропијата $(S)$ и промените во енталпијата $(H)$ и температурата. Покрај тоа се пресметани хиперполаризабилноста од прв ред, NBO, HOMO и LUMO енергиите, функцијата на Fukui и молекулскиот елетростатички потенцијал.

Клучни зборови: DFT; FT-IR спектри; FT-рамански спектри; функција на Fukui; $N^{\prime}$-(арилметилиден)тиофен-2-карбохидрзид 


\section{INTRODUCTION}

After the discovery of isonicotinic acid hydrazide (INH) as an effective antitubercular drug [1], heterocyclic hydrazides and their $N^{\prime}$-arylidene derivatives received considerable attention for their remarkable biological activities. As a result of an extensive search based on homocyclic and heterocyclic hydrazides and hydrazones, several derivatives were developed and proved to be superior to INH [2-8]. In addition, several hydrazide and hydrazine derivatives were reported to possess marked antifungal [9-12], antileishmanial [13, 14], antiviral [15], anticancer [16-18], anti-inflammatory [19] and antioxidant [20] activities. Moreover, carbohydrazide-hydrazones are utilized as efficient intermediates for the synthesis of several biologically-active heterocyclic compounds. The reaction of carbohydrazide-hydrazones with thioglycolic acid, chloroacetyl chloride, acetic anhydride and diazomethane yields the 4-thiazolidinone [21, 22], 2-azetidinone [22, 23], 1,3,4-oxadiazole [24-28] and 1,2,3-triazole [29] analogues, respectively.

The title compound, which is the isosteric analogue of INH hydrazones, was prepared as a precursor for potential chemotherapeutic agents [30]. A detailed study of the structural properties and spectroscopic profile of the title compound, containing the carbohydrazide-hydrazone moiety would significantly contribute to the synthesis surpassing derivatives with potential biological activities. In the present study, a comprehensive investigation on the molecular structure, electronic properties, thermodynamic properties, Fukui function and vibrational spectra of the title compound has been reported.

\section{EXPERIMENTAL DETAILS}

The title compound (molecular formula $\mathrm{C}_{12} \mathrm{H}_{9} \mathrm{FN}_{2} \mathrm{OS}$ ) in solid form was synthesized with a 90\% yield via heating thiophene-2-carbohydrazide with 4-fluoroaniline under reflux for one hour, and the product was precipitated on cooling. Pure single crystals suitable for XRD were obtained by recrystallization from ethanol (MP: 447-448 K). ${ }^{1} \mathrm{H}$ NMR (DMSO-d $\left.6,500.13 \mathrm{MHz}\right): \delta 7.22(\mathrm{t}, 1 \mathrm{H}$, thiophene-H, $J=3.5 \mathrm{~Hz}), 7.30-7.31(\mathrm{~m}, 2 \mathrm{H}, \mathrm{Ar}-$ $\mathrm{H}), 7.80-7.95(\mathrm{~m}, 4 \mathrm{H}, 2$ thiophene-H and $2 \mathrm{Ar}-\mathrm{H})$, $8.12(\mathrm{~s}, 1 \mathrm{H}, \mathrm{CH}=\mathrm{N}), 8.41(\mathrm{~s}, 1 \mathrm{H}, \mathrm{NH})$. The structure was further supported by single crystal X-ray spectroscopy [30]. The Fourier transform infrared (FTIR) spectrum of this compound was recorded in the region $4000-500 \mathrm{~cm}^{-1}$ on a Bruker model IFS
$66 \mathrm{~V}$ spectrophotometer (Ettlingen, Germany) using the $\mathrm{KBr}$ pellet technique. The FT-Raman spectrum was recorded on a BRUKER RFS 100/s FT-Raman instrument (Bruker Optics, Seoul, Korea) equipped with a Nd:YAG laser source operating at a wavelength of $1064 \mathrm{~nm}$ wavelength and $150 \mathrm{mw}$ power in the $4000-500 \mathrm{~cm}^{-1}$ range. The measured FT-IR and FT-Raman spectra along with theoreticallyconstructed spectra are shown in Figures 1 and 2.

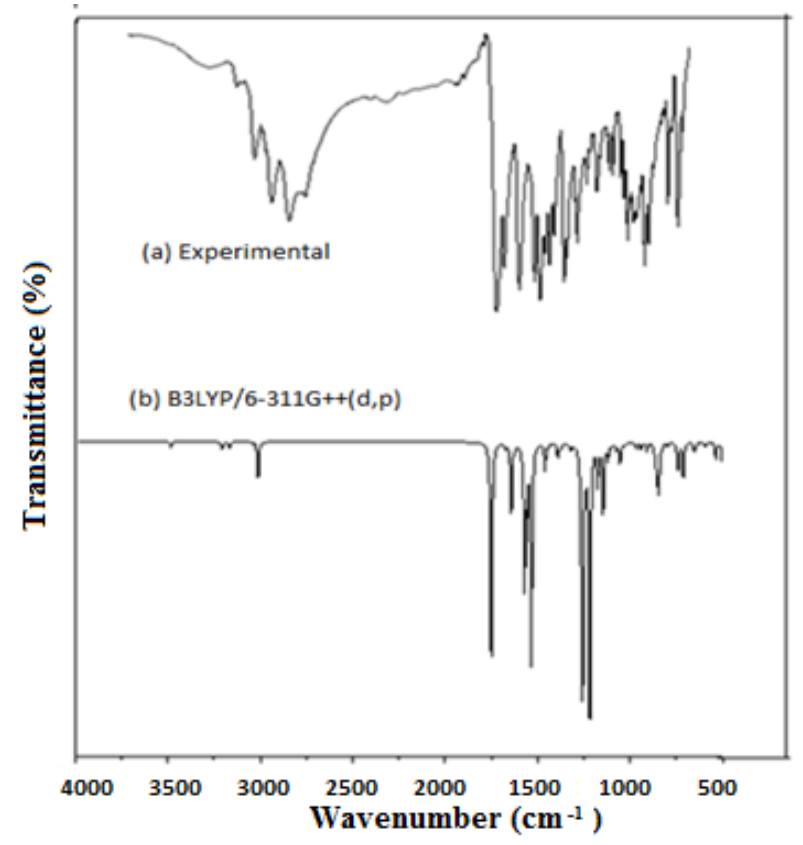

Fig. 1. Experimental and theoretical FT-IR spectra of the title compound

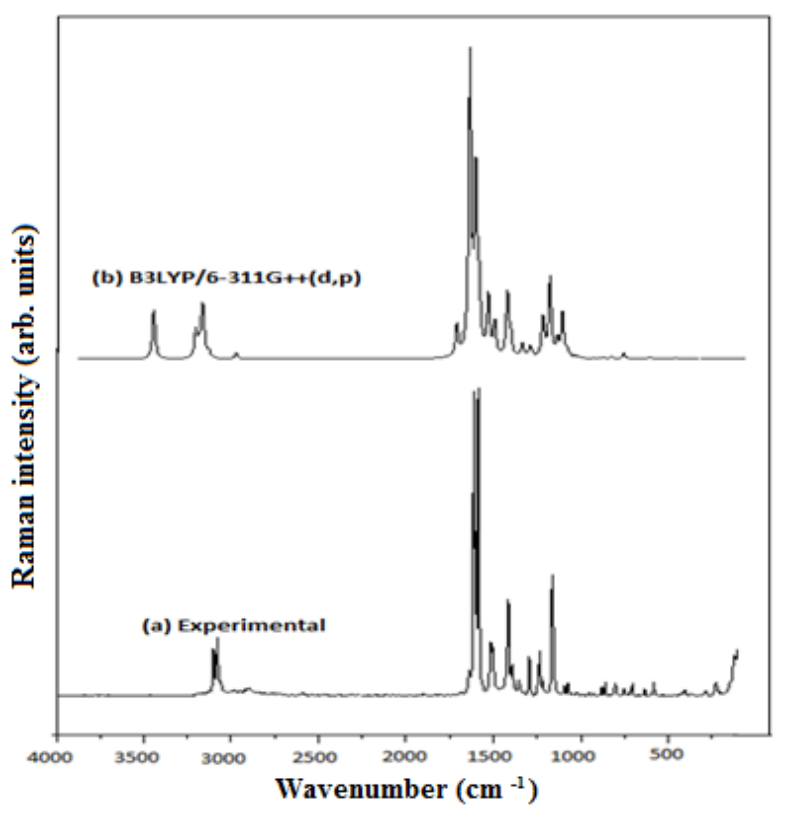

Fig. 2. Experimental and theoretical FT-Raman spectra of the title compound 


\section{COMPUTATIONAL DETAILS}

The entire set of calculations was performed at the density functional theory (DFT) level on a PC by energy optimization [31] using the GAUSSIAN 03W (Wallingford, CT, USA) program package [32]. In order to fit the theoretical wavenumbers to the experimental, scaling factors have been introduced by using a least square optimization of the computed to the experimental data. Vibrational frequencies are in the range of wavenumbers above $1700 \mathrm{~cm}^{-1}$ are scaled to 0.958 and below $1700 \mathrm{~cm}^{-1}$ are scaled to 0.983 for B3LYP/6$311++\mathrm{G}(\mathrm{d}, \mathrm{p})$ [33] to account for systematic errors caused by basis set incompleteness, neglect of electron correlation and vibrational anharmonicity. The NBO calculations [34] were performed using the NBO 3.1 program as implemented in the Gaussian 03W software at the above said level in order to understand various second-order interactions between the filled orbital of one subsystem and vacant orbital of another subsystem, which is a measure of the intermolecular and intramolecular delocalization or hyperconjugation. The first hyperpolarizabilities and related properties $\left(\beta_{\text {tot }} \alpha\right.$, $\Delta \alpha)$ of the title compound were calculated using the B3LYP/6-311++G(d,p) basis set. The electronic properties such as HOMO and LUMO energies are determined by the TD-DFT approach. The thermodynamic functions are calculated by the B3LYP/6-311++G(d,p) method.

The Raman activities $\left(S_{\mathrm{i}}\right)$, calculated with the GAUSSIAN 03W program, were subsequently converted to relative Raman intensities $\left(I_{\mathrm{i}}\right)$ using the following relationship derived from the theory of Raman scattering [35, 36]:

$$
I_{i}=\frac{f\left(v_{0}-v_{i}\right)^{4} S_{i}}{v_{i}\left(1-e^{\frac{\left.h c v_{i}\right)}{k_{b} T}}\right)}
$$

where $v_{0}$ is the excitation frequency in $\mathrm{cm}^{-1}, v_{i}$ is the vibrational wavenumber of the $i^{\text {th }}$ normal mode $h, c$ and $k_{b}$ are the fundamental constants and $f$ is a normalization factor for all peak intensities.

\section{RESULTS AND DISCUSSION}

\subsection{Molecular geometry}

The numbering system adopted in the molecular structure of the title molecules is shown in
Figure 3. A comparison table for the calculated bond lengths and angles with those of experimentally available XRD data [30] are listed in Table 1. From the theoretical values, it was observed that some of the calculated parameters slightly deviated from experimental values, due to the fact that the theoretical calculations belong to a molecule in the gaseous phase and the experimental results belong to a molecule in the solid state. The molecule has eight $\mathrm{C}-\mathrm{H}$ bond lengths, eleven $\mathrm{C}-\mathrm{C}$ bond lengths, two C-N bond lengths, two C-S bond lengths, and one N-H, C-F, C-O bond length. The C-C bond length of the ring was found to be about $1.4 \AA$ by the DFT method with the $6-311++\mathrm{G}(\mathrm{d}, \mathrm{p})$ basis set and agrees well with the experimental value. The calculated bond lengths for $\mathrm{C}-\mathrm{H}$ vary from 1.07 to $1.09 \AA$ and the $\mathrm{N}-\mathrm{H}$ bond length is about $1.0 \AA$. The C-S bond length is compared to other bond lengths. Several researchers have explained changes in the frequency or bond length of the $\mathrm{C}-\mathrm{H}$ bond upon substitution due to a change of the distribution on the carbon atoms of the benzene ring.

\subsection{Thermodynamic properties}

On the basis of vibrational analysis and statistical thermodynamics, the standard thermodynamic functions of heat capacity $(\mathrm{Cp})$ entropy $(\mathrm{S})$ and enthalpy changes $(\mathrm{H})$ for the title molecule were obtained from the theoretical harmonic frequencies, and are listed in Table 2. From Table 2, it can be observed that these thermodynamic functions increase with temperature in the range of 100 to $1000 \mathrm{~K}$, due to the fact that the molecular vibrational intensities increase with temperature. The correlation equations between heat capacity, entropy, enthalpy changes and temperatures were fitted by quadratic formulae, and the corresponding fitting factors $\left(R^{2}\right)$ for these thermodynamic properties are $1.0000,0.999$ and 0.999 , respectively. The corresponding fit equations are as follows, the correlation graphs are shown in Figure 4.

$$
\begin{array}{ll}
C=266.9+0.962 T-0.0002 T^{2} & \left(R^{2}=1.000\right) \\
S=18.46+0.868 T-0.0004 T^{2} & \left(R^{2}=0.999\right) \\
H=-10.85+0.117 T+0.0002 T^{2} & \left(R^{2}=0.999\right)
\end{array}
$$

These data helped to provide information for further study on the title compound in order to calculate the other thermodynamic energies according to the relationships between thermodynamic functions and to estimate the directions of the chemical reactions according to the second law of thermodynamics. 
Table 1

The optimized parameters (bond lengths and bond angle of the title compound)

\begin{tabular}{|c|c|c|}
\hline Parameters & B3LYP/6-311++G(d,p) & $\begin{array}{l}\text { Experi- } \\
\text { mental* }\end{array}$ \\
\hline \multicolumn{3}{|c|}{ Bond length $(\AA)$} \\
\hline $\mathrm{C} 1-\mathrm{C} 2$ & 1.372 & 1.362 \\
\hline C1-S5 & 1.751 & 1.714 \\
\hline C1-C6 & 1.486 & 1.476 \\
\hline $\mathrm{C} 2-\mathrm{C} 3$ & 1.42 & 1.388 \\
\hline C2-H18 & 1.081 & 1.08 \\
\hline $\mathrm{C} 3-\mathrm{C} 4$ & 1.368 & 1.361 \\
\hline C3-H19 & 1.082 & - \\
\hline C4-S5 & 1.729 & 1.725 \\
\hline $\mathrm{C} 4-\mathrm{H} 20$ & 1.079 & - \\
\hline C6-O7 & 1.213 & - \\
\hline C6-N8 & 1.389 & 1.283 \\
\hline N8-N9 & 1.354 & 1.370 \\
\hline N8-H21 & 1.017 & 0.90 \\
\hline N9-C10 & 1.28 & 1.283 \\
\hline C10-C11 & 1.463 & 1.465 \\
\hline $\mathrm{C} 10-\mathrm{H} 22$ & 1.098 & - \\
\hline $\mathrm{C} 11-\mathrm{C} 12$ & 1.402 & 1.394 \\
\hline C11-C16 & 1.406 & 1.392 \\
\hline C12-C13 & 1.392 & 1.388 \\
\hline C12-H23 & 1.085 & 0.95 \\
\hline C13-C14 & 1.385 & 1.374 \\
\hline C13-H24 & 1.083 & - \\
\hline C14-C15 & 1.39 & 1.380 \\
\hline C14-F17 & 1.354 & 1.363 \\
\hline C15-C16 & 1.387 & 1.386 \\
\hline C15-H25 & 1.083 & 0.950 \\
\hline C16-H26 & 1.083 & 0.950 \\
\hline \multicolumn{3}{|c|}{ Bond angle $\left({ }^{\circ}\right)$} \\
\hline $\mathrm{C} 2-\mathrm{C} 1-\mathrm{S} 5$ & 110.5 & 111.1 \\
\hline $\mathrm{C} 2-\mathrm{C} 1-\mathrm{C} 6$ & 124 & - \\
\hline $\mathrm{C} 1-\mathrm{C} 2-\mathrm{C} 3$ & 113.4 & 112.4 \\
\hline C1-C2-H18 & 121.6 & 123.8 \\
\hline S5-C1-C6 & 125.4 & - \\
\hline C1-S5-C4 & 91.6 & 91.6 \\
\hline C1-C6-O7 & 121.9 & - \\
\hline C1-C6-N8 & 114.6 & - \\
\hline C3-C2-H18 & 125 & 123.8 \\
\hline C2-C3-C4 & 112.8 & 114.3 \\
\hline C2-C3-H19 & 124 & 122.8 \\
\hline C4-C3-H19 & 123.2 & 122.8 \\
\hline C3-C4-S5 & 111.7 & 109.9 \\
\hline C3-C4-H2O & 128.6 & - \\
\hline $\mathrm{S} 5-\mathrm{C} 4-\mathrm{H} 20$ & 119.7 & 119.21 \\
\hline O7-C6-N8 & 123.5 & - \\
\hline C6-N8-N9 & 120.9 & 121.3 \\
\hline C6-N8-H21 & 119.7 & 118.1 \\
\hline N9-N8-H21 & 119.2 & 120.0 \\
\hline N8-N9-C10 & 117.5 & - \\
\hline N9-C10-C11 & 121.9 & 120.68 \\
\hline N9-C10-H22 & 121.4 & 119.7 \\
\hline C11-C10-H22 & 116.6 & 119.7 \\
\hline
\end{tabular}

\begin{tabular}{lcc}
\hline \hline Parameters & B3LYP/6-311++G(d,p) & $\begin{array}{c}\text { Experi- } \\
\text { mental* }\end{array}$ \\
\hline C11-C10-H22 & Bond angle( $\circ$ & \\
C10-C11-C12 & 116.6 & 119.7 \\
C10-C11-C16 & 119.4 & 119.2 \\
C12-C11-C16 & 121.7 & 122.06 \\
C11-C12-C13 & 118.9 & 118.76 \\
C11-C12-H23 & 121 & 121.31 \\
C11-C16-C15 & 119.7 & 119.3 \\
C11-C16-H26 & 120.6 & 120.73 \\
C13-C12-H23 & 119 & 119.3 \\
C12-C13-C14 & 119.2 & -121.0 \\
C12-C13-H24 & 121.8 & - \\
C14-C13-H24 & 119.9 & 122.72 \\
C13-C14-C15 & 122.4 & 118.8 \\
C13-C14-F17 & 118.9 & 118.46 \\
C15-C14-H17 & 118.8 & 118.51 \\
C14-C15-C16 & 118.8 & 120.7 \\
C14-C15-H25 & 119.7 & 120.7 \\
C16-C15-H25 & 121.6 & 119.6 \\
C15-C16-H26 & 120.4 & - \\
\hline \hline
\end{tabular}

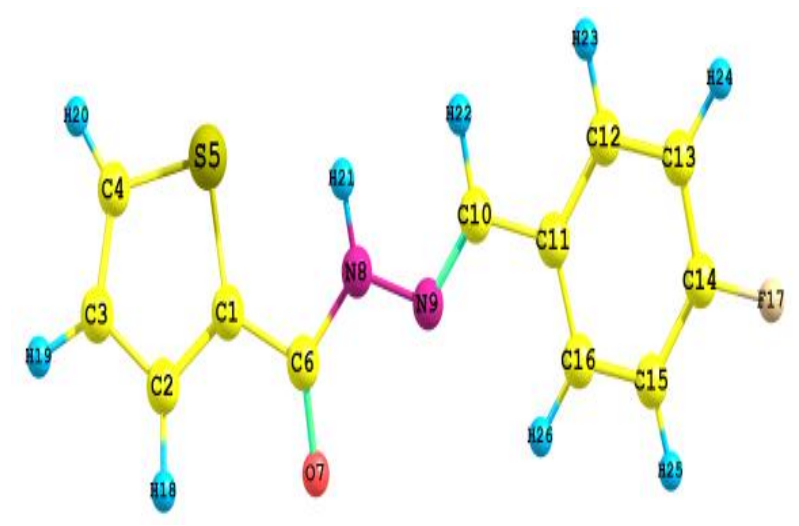

Fig. 3. Optimized ground state structure of the title compound (B3LYP/6-311++G(d,p)

T a b le 2

Thermodynamic properties for the title compound $B 3 L Y P / 6-311++G(d, p)$

\begin{tabular}{lccc}
\hline \hline $\boldsymbol{T}(\mathbf{K})$ & $\boldsymbol{S} \mathbf{( J / m o l} \cdot \mathbf{K})$ & $\boldsymbol{C}_{\mathbf{p}}(\mathbf{c a l} / \mathbf{m o l} \cdot \mathbf{K})$ & $\boldsymbol{H}(\mathbf{k c a l} / \mathbf{m o l})$ \\
\hline 100 & 358.8 & 104.63 & 7.24 \\
200 & 451.3 & 171.56 & 20.97 \\
298.15 & 532.86 & 241.33 & 41.25 \\
300 & 534.36 & 242.61 & 41.69 \\
400 & 613.21 & 306.91 & 69.26 \\
500 & 687.58 & 359.63 & 102.68 \\
600 & 756.99 & 401.36 & 140.81 \\
700 & 821.43 & 434.43 & 182.67 \\
800 & 881.25 & 461.07 & 227.49 \\
900 & 936.85 & 482.89 & 274.72 \\
1000 & 988.7 & 501.03 & 323.94 \\
\hline \hline
\end{tabular}




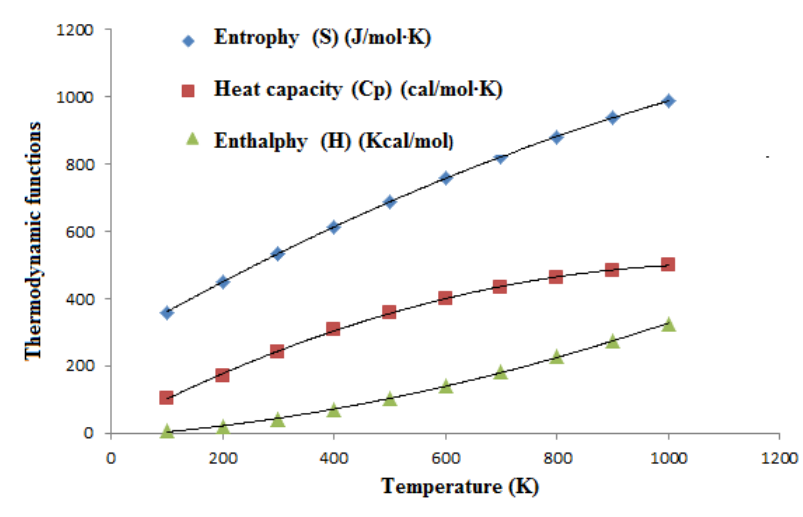

Fig. 4. Correlation graphs of entropy, heat capacity and enthalpy changes of the title compound with various temperature

\subsection{Nonlinear optical (NLO) properties}

The transmission spectra of NLO materials are very important because NLO materials have practical use if they have a wide transparency window. Hyperpolarizabilities are very sensitive to the basis sets and the level of the employed theoretical approach [37, 38], so that the electron correlation can change the value of hyperpolarizability. Urea is one of the prototypical molecules used in the study of NLO properties of molecular systems. Therefore, it has been used frequently to establish a threshold value for comparative purposes. The calculations of the total molecular dipole moment $\left(\mu_{\mathrm{D}}\right)$, linear polarizability $(\alpha)$ and first-order hyperpolarizability $\left(\beta_{\mathrm{tot}}\right)$ from the Gaussian output have been previously explained in detail and the DFT has been extensively used as an effective method to investigate organic NLO materials [39]. The polar properties of the title compound were calculated by the DFT method. The non-zero values of the dipole moment accurately depict the dipolar character of the optimized molecules. From Table 3, it can be observed that the calculated first-order hyperpolarizability value of the title compound is $1.1769 \times 10^{-30} \mathrm{esu}$, which is nearly three times that of urea. The high $\beta$ value and non-zero value of $\mu$ are responsible for the second-order non-linear optical properties. Therefore, the values suggest the possibility of technological applications.

Ta ble 3

The values of calculated $\mu_{D}, \alpha_{0}$ and $\beta_{\text {total }}$ components of the title compound

\begin{tabular}{cccc}
\hline \hline Parameters & B3LYP/6-311++G(d,p) & Parameters & B3LYP/6-311++G(d,p) \\
\hline$\mu_{\mathrm{x}}$ & -0.01115 & $\beta_{\mathrm{xxx}}$ & -1073.48179 \\
$\mu_{\mathrm{y}}$ & 1.35947 & $\beta_{\mathrm{xxy}}$ & 142.7065 \\
$\mu_{\mathrm{z}}$ & 0.17279 & $\beta_{\mathrm{xyy}}$ & -38.1848 \\
$\mu_{\mathrm{D}}$ & 1.37045 & $\beta_{\mathrm{yyy}}$ & 79.8134 \\
$\alpha_{\mathrm{xx}}$ & 244.8136 & $\beta_{\mathrm{xxz}}$ & 374.4073 \\
$\alpha_{\mathrm{xy}}$ & -31.4252 & $\beta_{\mathrm{xyz}}$ & -124.54847 \\
$\alpha_{\mathrm{yy}}$ & 165.9124 & $\beta_{\mathrm{yyz}}$ & 40.2489 \\
$\alpha_{\mathrm{xz}}$ & 79.91244 & $\beta_{\mathrm{xzz}}$ & -121.85234 \\
$\alpha_{\mathrm{yz}}$ & 1.5548 & $\beta_{\mathrm{yzz}}$ & 119.3764 \\
$\alpha_{\mathrm{zz}}$ & 121.5548 & $\beta_{\mathrm{zzz}}$ & 51.5633 \\
$\left(\alpha_{0}\right)$ (esu) & $2.6254 X 10^{-23}$ & $\beta_{\text {total }}(\mathrm{esu})$ & $1.1769 \times 10^{-30}$ \\
$\Delta \alpha_{(\mathrm{esu})}$ & $6.4857 \times 10^{-23}$ & & \\
\hline \hline
\end{tabular}

\subsection{Molecular electrostatic potential (MEP)}

The molecular electrostatic potential is related to the electron density and is a very useful descriptor for determining the sites for electrophilic and nucleophilic reactions as well as hydrogen bonding interactions [40]. To predict the reactive sites for electrophilic and nucleophilic attacks for the title molecule, the molecular electrostatic potential (MEP) at the B3LYP/6-311++G(d,p) optimized geometry was calculated. The 3D plots of the MEP of the title compound are illustrated in Figure 5.

The different values of the electrostatic potential at the surface of the molecule are represented by different colors. Increases in potential are identified by color in the order of red < orange $<$ yellow < blue. The color code of these maps ranges from $-6.697 \mathrm{eV}$ and $+6.697 \mathrm{eV}$, where blue indicates the strongest attraction and yellow indicates repulsion. As can be seen from the MEP of 
the title compound, while the regions with negative potentials are over the electronegative atoms (sulfur, fluorine, nitrogen and oxygen), the regions with positive potentials are over the hydrogen atoms. From this result, we can conclude that the $\mathrm{H}$ atoms are the locations of the strongest attraction and the $\mathrm{N}, \mathrm{O}, \mathrm{F}$ and $\mathrm{S}$ atoms are the sites of repulsion. The contour map of the electrostatic potential (Fig. 6) also confirms the different negative and positive potential sites of the molecule, in accordance with the total electron density surface map.

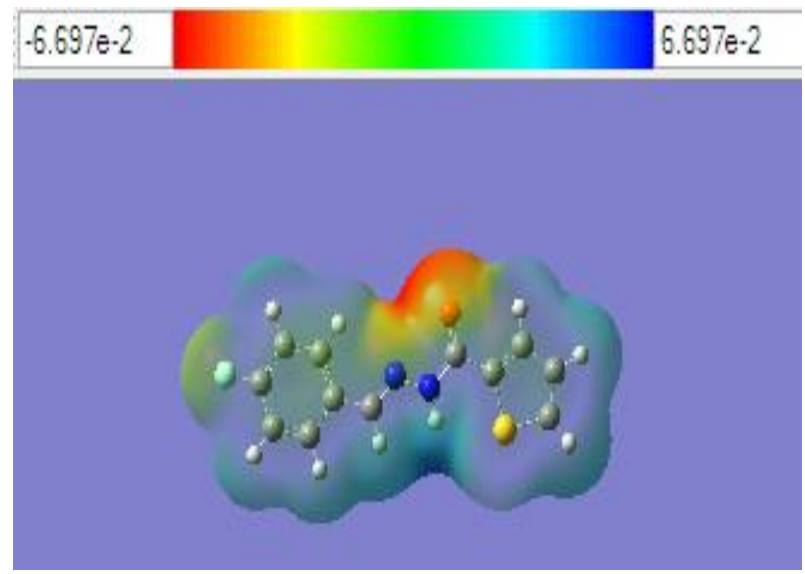

Fig. 5. The total electron density surface 3D mapped with electrostatic potential of the title compound

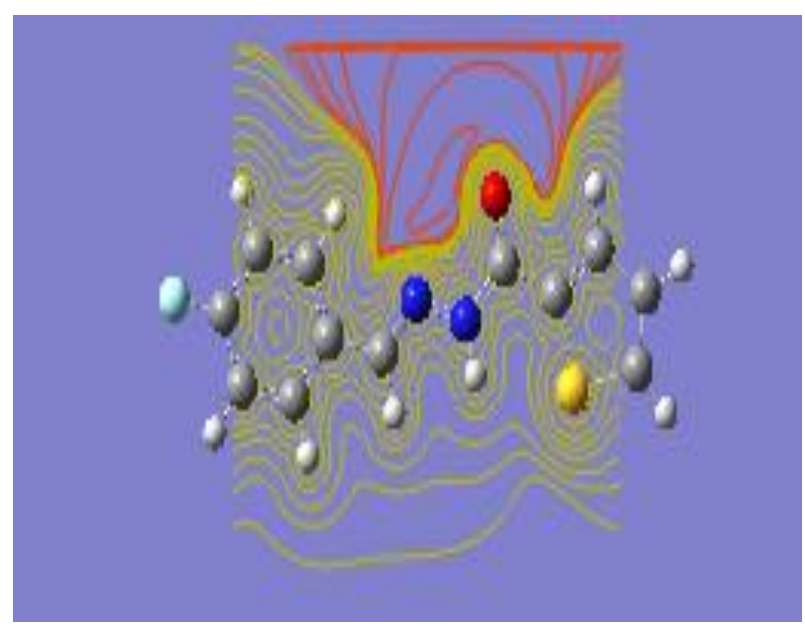

Fig. 6. 2D contour map of the electrostatic potential of the total density of the title compound

\subsection{Natural bond orbital (NBO) analysis}

The natural bond orbital analysis provides the most accurate 'natural Lewis structure' picture of $\phi$, because all the orbital details are mathematically chosen to include the highest possible percentage of the electron density. The NBO method is useful in that it provides information about interactions in both filled and virtual orbital spaces that could enhance the analysis of intra- and intermolecular interactions. The second-order Fock matrix was applied to evaluate the donor-acceptor interactions in the NBO analysis [41]. The result of these interactions is a loss of occupancy from the localized NBO of the idealized Lewis structure into an empty non-Lewis orbital. For each donor (i) and acceptor (j), the stabilization energy $E(2)$ associated with the delocalization $\mathrm{i} \rightarrow \mathrm{j}$ is estimated as follows:

$$
E(2)=\Delta E_{i j}=q_{i} \frac{\left(F_{i, j}\right)^{2}}{\left(E_{j}-E_{i}\right)}
$$

where $q_{i}$ is the donor orbital occupancy, $E_{\mathrm{i}}$ and $E_{\mathrm{j}}$ are diagonal elements and $F(\mathrm{i}, \mathrm{j})$ is the off diagonal NBO Fock matrix element. The NBO analysis provides an efficient method for studying the intraand intermolecular bonding and the interaction among bonds and also provides a convenient basis for investigating charge transfer or conjugative interaction in molecular systems. Some electron donor orbitals, acceptor orbitals and the interacting stabilization energies resulting from the secondorder micro-disturbance theory are reported [42]. The larger the $E(2)$ value, the more intense the interaction between electron donors and electron acceptors. Delocalization of electron density between occupied Lewis-type (bond or lone pair) NBO orbitals and formally unoccupied (anti-bond or Rydberg) non-Lewis NBO orbitals corresponds to a stabilizing donor-acceptor interaction. The NBO analysis has been performed on the title molecule at the DFT/B3LYP6-311++G (d,p) level in order to elucidate the delocalization of electron density within the molecule.

The intramolecular hyperconjugative interaction of $\sigma\left(\mathrm{C}_{1}-\mathrm{C}_{2}\right)$ distributed to $\sigma^{*}\left(\mathrm{C}_{2}-\mathrm{C}_{3}\right)$ resulting in a stabilization of $2.07 \mathrm{~kJ} / \mathrm{mole}$. This enhanced further conjugations with the $\pi^{*}\left(\mathrm{C}_{3}-\mathrm{C}_{4}\right)$ antibonding orbital with a stabilization energy of $16.4 \mathrm{~kJ} / \mathrm{mole}$. In the title compound, the $\pi\left(\mathrm{C}_{13}-\mathrm{C}_{14}\right)$ orbital, the $\pi^{*}\left(\mathrm{C}_{15}-\mathrm{C}_{16}\right),\left(\mathrm{C}_{11}-\mathrm{C}_{12}\right)$, show stabilization energies of $16.27 \mathrm{~kJ} / \mathrm{mole}$ and $20.61 \mathrm{~kJ} / \mathrm{mole}$, respectively. The magnitude of charge transferred from $\mathrm{N}_{9} \mathrm{Lp}$ (1) $\left(\mathrm{C}_{10}-\mathrm{H}_{22}\right)$ shows a stabilization of $10.89 \mathrm{~kJ} / \mathrm{mole}$. Similarly, the electron donation from $S_{5} L p(2)$ to the antibonding $\left(\mathrm{C}_{1}-\mathrm{C}_{2}\right),\left(\mathrm{C}_{3}-\mathrm{C}_{4}\right)$ results in a stabilization of about $14 \mathrm{~kJ} / \mathrm{mole}$ as shown in Table 4. 
T a b le 4

Second order perturbation theory analysis of Fock matrix in NBO basis

\begin{tabular}{|c|c|c|c|c|c|c|c|c|}
\hline Donor(i) & Type & ED/e & Acceptor(i) & Type & ED/e & $E(2)^{\mathrm{a}}\left(\mathrm{kJ} \cdot \mathrm{mol}^{-1}\right)$ & $E(\mathbf{j})-E(\mathbf{i})^{\mathbf{b}}($ a.u. $)$ & $F(\mathbf{i}, \mathbf{j})^{\mathbf{c}}(\mathbf{a} . \mathbf{u})$. \\
\hline \multirow[t]{5}{*}{$\mathrm{C} 1-\mathrm{C} 2$} & $\sigma$ & 1.98186 & C1-C6 & $\sigma^{*}$ & 0.08493 & 1.76 & 1.14 & 0.041 \\
\hline & & & $\mathrm{C} 2-\mathrm{C} 3$ & $\sigma^{*}$ & 0.01155 & 2.07 & 1.19 & 0.044 \\
\hline & & & C2-H18 & $\sigma^{*}$ & 0.01659 & 1.66 & 1.18 & 0.039 \\
\hline & & & C3-H19 & $\sigma^{*}$ & 0.0142 & 1.83 & 1.2 & 0.042 \\
\hline & & & C6-N8 & $\sigma^{*}$ & 0.08473 & 1.67 & 1.21 & 0.041 \\
\hline $\mathrm{C} 1-\mathrm{C} 2$ & $\pi$ & 1.82264 & $\mathrm{C} 3-\mathrm{C} 4$ & $\pi^{*}$ & 0.28389 & 16.4 & 0.25 & 0.059 \\
\hline $\mathrm{N} 8-\mathrm{H} 21$ & $\sigma$ & 1.98192 & C6-O7 & $\sigma^{*}$ & 0.0119 & 3.97 & 1.31 & 0.065 \\
\hline \multirow[t]{4}{*}{ C13-C14 } & $\sigma$ & 1.98227 & $\mathrm{C} 12-\mathrm{C} 13$ & $\sigma^{*}$ & 0.01034 & 1.85 & 1.24 & 0.043 \\
\hline & & & $\mathrm{C} 12-\mathrm{H} 23$ & $\sigma^{*}$ & 0.01237 & 2.16 & 1.12 & 0.044 \\
\hline & & & $\mathrm{C} 14-\mathrm{C} 15$ & $\sigma^{*}$ & 0.02788 & 3.12 & 1.22 & 0.055 \\
\hline & & & $\mathrm{C} 15-\mathrm{H} 25$ & $\sigma^{*}$ & 0.01106 & 1.99 & 1.12 & 0.042 \\
\hline \multirow[t]{3}{*}{ C13-C14 } & $\pi$ & 1.64542 & $\mathrm{C} 11-\mathrm{C} 12$ & $\pi^{*}$ & 0.02788 & 20.61 & 0.28 & 0.069 \\
\hline & & & $\mathrm{C} 13-\mathrm{C} 14$ & $\pi^{*}$ & 0.37 & 0.79 & 0.27 & 0.013 \\
\hline & & & $\mathrm{C} 15-\mathrm{C} 16$ & $\pi^{*}$ & 0.29777 & 16.27 & 0.28 & 0.062 \\
\hline \multirow[t]{4}{*}{$\mathrm{C} 15-\mathrm{C} 16$} & $\sigma$ & 1.97714 & $\mathrm{C} 10-\mathrm{C} 11$ & $\sigma^{*}$ & 0.03044 & 3.39 & 1.12 & 0.055 \\
\hline & & & $\mathrm{C} 11-\mathrm{C} 16$ & $\sigma^{*}$ & 0.02242 & 2.32 & 1.23 & 0.048 \\
\hline & & & C14-C15 & $\sigma^{*}$ & 0.02788 & 1.63 & 1.2 & 0.04 \\
\hline & & & C14-F17 & $\sigma^{*}$ & 0.02679 & 3.71 & 0.98 & 0.054 \\
\hline \multirow[t]{4}{*}{$\mathrm{C} 15-\mathrm{C} 16$} & $\sigma$ & 1.97714 & C10-C11 & $\sigma^{*}$ & 0.03044 & 3.39 & 1.12 & 0.055 \\
\hline & & & C11-C16 & $\sigma^{*}$ & 0.02242 & 2.32 & 1.23 & 0.048 \\
\hline & & & C14-C15 & $\sigma^{*}$ & 0.02788 & 1.63 & 1.2 & 0.04 \\
\hline & & & C14-F17 & $\sigma^{*}$ & 0.02679 & 3.71 & 0.98 & 0.054 \\
\hline \multirow[t]{2}{*}{$\mathrm{C} 15-\mathrm{C} 16$} & $\pi$ & 1.67685 & $\mathrm{C} 11-\mathrm{C} 12$ & $\pi^{*}$ & 0.38267 & 17.82 & 0.27 & 0.063 \\
\hline & & & C13-C14 & $\pi^{*}$ & 0.37 & 22.67 & 0.26 & 0.069 \\
\hline \multirow[t]{2}{*}{ S5 } & LP (2) & 1.68295 & $\mathrm{C} 1-\mathrm{C} 2$ & $\pi^{*}$ & 0.29206 & 13.98 & 0.27 & 0.055 \\
\hline & & & C3-C4 & $\pi^{*}$ & 0.28389 & 14.44 & 0.22 & 0.05 \\
\hline \multirow[t]{3}{*}{ N9 } & LP (1) & 1.90501 & N8-H21 & $\sigma^{*}$ & 0.03156 & 4.29 & 0.74 & 0.051 \\
\hline & & & $\mathrm{C} 10-\mathrm{C} 11$ & $\sigma^{*}$ & 0.03044 & 2.51 & 0.79 & 0.04 \\
\hline & & & $\mathrm{C} 10-\mathrm{H} 22$ & $\sigma^{*}$ & 0.03886 & 10.89 & 0.74 & 0.081 \\
\hline \multirow[t]{2}{*}{ F17 } & $\mathrm{LP}(1)$ & 1.98859 & C13-C14 & $\sigma^{*}$ & 0.02769 & 1.16 & 1.54 & 0.038 \\
\hline & & & C14-C15 & $\sigma^{*}$ & 0.02788 & 1.17 & 1.54 & 0.038 \\
\hline
\end{tabular}

${ }^{a} E(2)$ - energy of hyperconjugative interaction (stabilization energy)

${ }^{\mathrm{b}}$ Energy difference between donor and acceptor I and $\mathrm{j}$ NBO orbitals

${ }^{\mathrm{c}} F(\mathrm{i} . \mathrm{j})$ - Fock matrix element between $i$ and $j$ NBO orbitals

\subsection{Frontier molecular orbital analysis}

Many organic molecules containing conjugated $\pi$ electrons and characterized by hyperpolarizabilities were analyzed by means of vibrational spectroscopy [43, 44]. In most cases, even in the absence of inversion symmetry, the strongest bands in the Raman spectrum are weak in the IR spectrum and vice versa. The intramolecular charge transfer from the donor to the acceptor group through a single-double bond conjugated path can induce large vibrations of both the molecular dipole moment and the molecular polarizability, making the IR and Raman activity strong. At the same time, the experimental spectroscopic behavior described above is well accounted for by $a b$ initio calculations in $\pi$ conjugated systems that predict exceptionally large Raman and infrared intensities for the same normal modes. The observation that bands in the FT-IR spectrum of the title molecule have their counterparts in the Raman spectrum shows that the relative intensities in the IR and Raman spectra are comparable, resulting from the electron cloud movement through the $\pi$ conjugated framework from the electron donor to the electron acceptor groups. The highest occupied molecular orbital (HOMO) and lowest unoccupied molecular orbital (LUMO) are very important pa- 
rameters for quantum chemistry. From this information, we can determine the way in which the molecule interacts with other species; hence, they are called the frontier orbitals. The HOMO, which can be thought of as the outer most orbital containing electrons, tends to give these electrons away as an electron donor. On the other hand, the LUMO can be thought of as the inner most orbital containing free places to accept electrons [45]. Owing to the interaction between the HOMO and LUMO orbital of a compound, the $\pi-\pi^{*}$ type transition state is observed with regard to molecular orbital theory [46]. Therefore, while the energy of the HOMO is directly related to the ionization potential, the LUMO energy is directly related to the electron affinity. The energy difference between the HOMO and LUMO orbitals is called the energy gap, which is an important stability factor for the compound [47]. The atomic orbital compositions of the frontier molecular orbital are sketched in Figure 7.
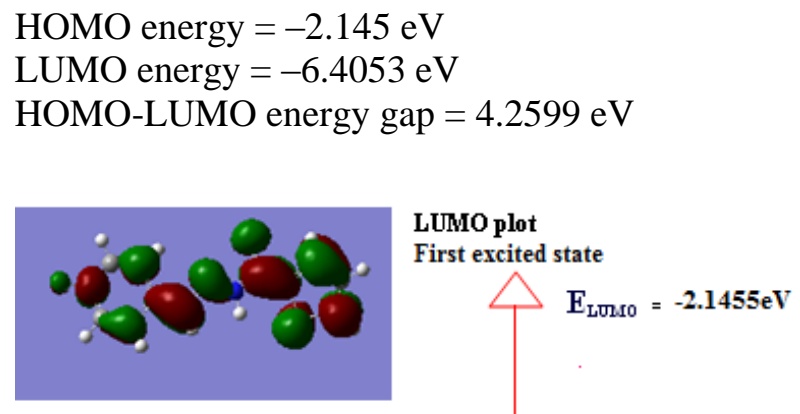

$\Delta \mathrm{E}=4.2599 \mathrm{eV}$

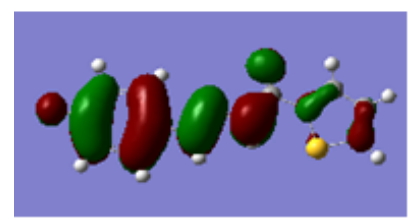

$$
\begin{aligned}
& \mathrm{E}_{\text {Hous }}=-6.4053 \mathrm{eV} \\
& \text { HOMO plot } \\
& \text { Ground state }
\end{aligned}
$$

Fig. 7. The atomic orbital compositions of the frontier molecular orbital of the title compound

\subsection{Sum of alpha plus beta electrons (DOS)}

In the boundary region, neighboring orbitals may show quasi degenerate energy levels. In such cases, consideration of only the HOMO and LUMO may not yield a realistic description of frontier orbitals. For this reason, the total density of states (TDOS), or the sum of $\alpha$ and $\beta$ electron density of states [48,49] in terms of Mülliken population analysis were calculated and created by convoluting the molecular orbital information with Gaussian curves of unit height and full width at the half maximum (FWHM) of $0.3 \mathrm{eV}$ by using the Gauss Sum 2.2 program [50]. The TDOS and $\alpha \beta D O S$ of the title compound are plotted in Figures 8 and 9, which provides a pictorial representation of the molecular orbital (MO) compositions and their contributions to chemical bonding. The most important application of DOS plots is to demonstrate the MO compositions and their contributions to chemical bonding through the positive and negative charges provided by $\alpha \beta D O S$ and TDOS diagrams. The $\alpha \beta D O S$ shows the bonding, sum of positive and negative electrons with the nature of the interaction of the two orbitals, atoms or groups. In this case, the title molecule consists of $64 \alpha$ electrons and $64 \beta$-electrons; in total 128 electrons are occupied in density of states.

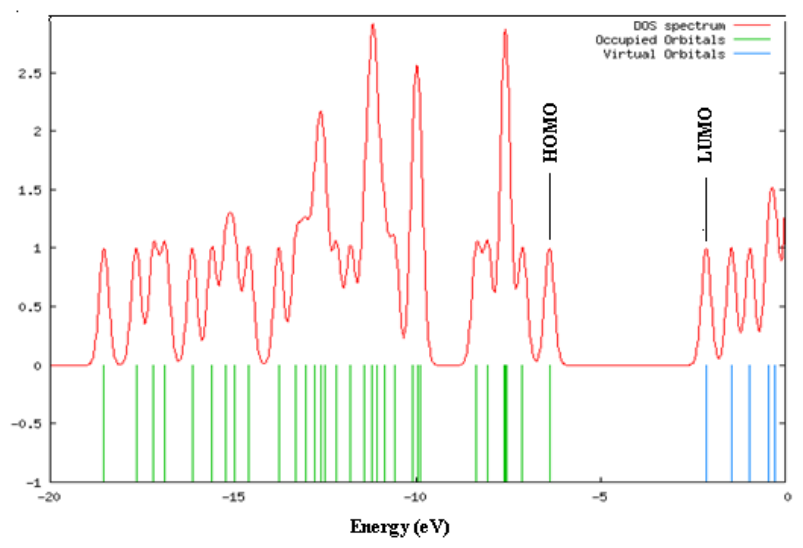

Fig. 8. The calculated TDOS diagram of the title compound

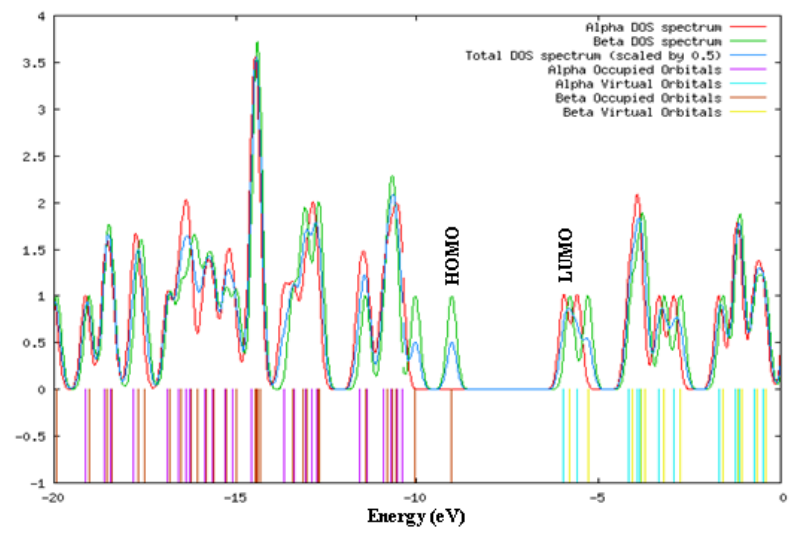

Fig. 9. The sum of alpha and beta electron DOS diagrams of the title compound

The way to designate a pictorial representation of the cations and anions is essentially similar to that of neutral atoms in their ground state. Because of the short range of absorption, alphas are not, in general, dangerous to life unless the source is ingested or inhaled, in which case they become extremely dangerous [51]. A positive $\alpha \beta \mathrm{DOS}$ value indicates a 
bonding interaction, whereas a negative value means that there is an anti-bonding interaction and a zero value indicates non-bonding interactions [52].

\subsection{Vibrational assignments}

The maximum number of potentially-active observable fundamental modes of a nonlinear mol- ecule, which contains $\mathrm{N}$ atoms, is equal to $(3 n-6)$, apart from three translational and three rotational degrees of freedom $[53,54]$. Hence, the title molecule has 26 atoms with 72 normal modes of vibrations considered under $\mathrm{C}_{1}$ point group symmetry. The detailed spectral assignments with PED contributions are shown in Table 5.

\section{Table 5}

The calculated and vibrational wavenumber, measured IR and Raman band position $\left(\mathrm{cm}^{-1}\right)$ and assignments of the title compound

\begin{tabular}{|c|c|c|c|c|c|c|c|c|}
\hline \multirow{2}{*}{$\begin{array}{c}\text { Mode } \\
\text { no. }\end{array}$} & \multicolumn{2}{|c|}{ Experimental } & \multirow{2}{*}{$\begin{array}{l}\text { Calculated } \\
\text { frequency }\end{array}$} & \multicolumn{2}{|c|}{ IR intensity ${ }^{\mathbf{a}}$} & \multicolumn{2}{|c|}{ Raman intensity $^{\mathbf{b}}$} & \multirow{2}{*}{$\begin{array}{l}\text { Vibrational assignments } \\
(\text { PED \%)c }\end{array}$} \\
\hline & FT-IR & FT-Raman & & rel & abs & rel & abs & \\
\hline 1 & 2 & 3 & 4 & 5 & 6 & 7 & 8 & 9 \\
\hline 1 & & & 3349 & 7 & 2 & 444 & 17 & NH str (100) \\
\hline 2 & 3124 & & 3119 & 0 & 0 & 238 & 9 & $\mathrm{CH}$ str (92) \\
\hline 3 & & 3101 & 3101 & 1 & 0 & 112 & 4 & CH str (88) \\
\hline 4 & & 3090 & 3083 & 3 & 1 & 129 & 5 & $\mathrm{CH}$ str (98) \\
\hline 5 & & 3080 & 3082 & 4 & 1 & 166 & 6 & CH str (99) \\
\hline 6 & & 3079 & 3079 & 4 & 1 & 173 & 6 & $\mathrm{CH}$ str (94) \\
\hline 7 & 3058 & & 3070 & 1 & 0 & 73 & 3 & $\mathrm{CH}$ str (99) \\
\hline 8 & & 3050 & 3045 & 8 & 2 & 56 & 2 & CH str (95) \\
\hline 9 & 2904 & 2895 & 2895 & 51 & 13 & 53 & 2 & CH str (100) \\
\hline 10 & 1654 & & 1682 & 306 & 79 & 280 & 10 & $\mathrm{CC} \operatorname{str}(86)$ \\
\hline 11 & 1609 & 1612 & 1610 & 7 & 2 & 2690 & 100 & CC $\operatorname{str}(67)$ \\
\hline 12 & & 1588 & 1579 & 100 & 26 & 1539 & 57 & $\mathrm{CC} \operatorname{str}(66)$ \\
\hline 13 & & & 1560 & 7 & 2 & 506 & 19 & $\mathrm{CC} \operatorname{str}(70)$ \\
\hline 14 & 1512 & 1513 & 1510 & 203 & 52 & 534 & 20 & $\mathrm{CC}$ str $(49)+\mathrm{CCH}$ ben $(28)$ \\
\hline 15 & & 1504 & 1497 & 68 & 18 & 3 & 0 & $\mathrm{CC}$ str $(70)+\mathrm{CCH}$ ben $(18)$ \\
\hline 16 & & & 1474 & 313 & 81 & 299 & 11 & CC $\operatorname{str}(68)+$ CCHben (12) \\
\hline 17 & 1417 & 1414 & 1404 & 39 & 10 & 578 & 22 & $\mathrm{CC} \operatorname{str}(69)+\mathrm{CCH}$ ben $(14)$ \\
\hline 18 & 1383 & 1392 & 1386 & 6 & 1 & 162 & 6 & $\mathrm{CC} \operatorname{str}(56)+\mathrm{CCH}$ ben $(32)$ \\
\hline 19 & 1352 & 1354 & 1336 & 20 & 5 & 17 & 1 & $\mathrm{CC} \operatorname{str}(69)+\mathrm{CH} \operatorname{str}(25)$ \\
\hline 20 & 1325 & & 1322 & 10 & 2 & 118 & 4 & $\begin{array}{l}\mathrm{CC} \operatorname{str}(40)+\mathrm{CCH} \text { ben }(24)+\mathrm{CO} \\
\operatorname{str}(16)\end{array}$ \\
\hline 21 & 1296 & 1294 & 1281 & 2 & 0 & 88 & 3 & $\begin{array}{l}\text { CNstr }(46)+\mathrm{CCH} \text { ben }(25)+\mathrm{CO} \\
\operatorname{str}(26)\end{array}$ \\
\hline 22 & & & 1270 & 9 & 2 & 31 & 1 & $\begin{array}{l}\mathrm{CCH} \text { ben }(52)+\mathrm{FC} \mathrm{str}(22)+\mathrm{CN} \\
\operatorname{str}(16)\end{array}$ \\
\hline 23 & 1232 & 1230 & 1211 & 230 & 60 & 197 & 7 & $\mathrm{CO} \operatorname{str}(76)+\mathrm{CCH}$ ben $(14)$ \\
\hline 24 & 1215 & 1216 & 1206 & 213 & 55 & 182 & 7 & $\begin{array}{l}\text { CNstr (41) + FC str (32) + HCN } \\
\text { ben (19) }\end{array}$ \\
\hline 25 & & & 1191 & 25 & 6 & 4 & 0 & $\begin{array}{l}\mathrm{FC} \operatorname{str}(62)+\mathrm{CCH} \text { ben }(12)+\mathrm{CN} \\
\operatorname{str}(16)\end{array}$ \\
\hline 26 & 1162 & 1162 & 1170 & 387 & 100 & 719 & 27 & $\begin{array}{l}\mathrm{CCH} \text { ben }(41)+\mathrm{CC} \text { str }(43)+ \\
\mathrm{CCC} \text { ben }(14)\end{array}$ \\
\hline 27 & 1152 & & 1130 & 59 & 15 & 146 & 5 & $\mathrm{CCH}$ ben $(49)+\mathrm{NN}$ str $(32)$ \\
\hline 28 & 1092 & 1092 & 1102 & 100 & 26 & 397 & 15 & $\mathrm{CCH}$ ben $(52)+\mathrm{CC}$ str $(43)$ \\
\hline 29 & & 1073 & 1077 & 23 & 6 & 53 & 2 & $\mathrm{CCH}$ ben $(46)+\mathrm{HCCC}$ out (42) \\
\hline 30 & & & 1061 & 4 & 1 & 15 & 1 & $\begin{array}{l}\mathrm{CCH} \text { ben }(49)+\mathrm{FC} \text { str }(14)+\mathrm{CO} \\
\text { str }(16)\end{array}$ \\
\hline 31 & 1025 & & 1032 & 11 & 3 & 16 & 1 & $\begin{array}{l}\mathrm{CCH} \text { ben }(48)+\mathrm{CN} \text { str }(31)+ \\
\mathrm{NN} \operatorname{str}(12)\end{array}$ \\
\hline 32 & & & 1013 & 31 & 8 & 9 & 0 & $\begin{array}{l}\mathrm{HCCC} \text { out }(58)+\mathrm{FC} \text { str }(24)+ \\
\mathrm{CO} \text { str }(11)\end{array}$ \\
\hline 33 & & & 988 & 4 & 1 & 7 & 0 & NN str (52)+ HCCC out (40) \\
\hline 34 & 952 & & 953 & 0 & 0 & 0 & 0 & HCCC out (47) + CCC ben (44) \\
\hline 35 & 929 & & 928 & 8 & 2 & 6 & 0 & HCCC out (48) + CNN ben (39) \\
\hline 36 & & & 905 & 9 & 2 & 3 & 0 & $\begin{array}{l}\text { HCCC out }(43)+\mathrm{CNH} \text { ben }(18) \\
+\mathrm{CNN} \text { ben }(19)\end{array}$ \\
\hline 37 & 879 & & 899 & 1 & 0 & 2 & 0 & HCCC out (59) +CCCben $(31)$ \\
\hline 38 & 859 & 879 & 874 & 13 & 3 & 17 & 1 & CNN ben $(55)+\mathrm{CCC}$ ben $(38)$ \\
\hline
\end{tabular}




\begin{tabular}{|c|c|c|c|c|c|c|c|c|}
\hline 1 & 2 & 3 & 4 & 5 & 6 & 7 & 8 & 9 \\
\hline 39 & 836 & & 837 & 6 & 1 & 2 & 0 & $\begin{array}{l}\text { CNH ben }(54)+\text { CCOben }(19)+ \\
\text { ONCC out }(14)\end{array}$ \\
\hline 40 & & & 831 & 8 & 2 & 19 & 1 & CCC ben (44) + OCN ben $(33)$ \\
\hline 41 & 822 & & 821 & 48 & 12 & 0 & 0 & CCC ben $(52)+C S \operatorname{str}(25)$ \\
\hline 42 & 802 & & 811 & 65 & 17 & 1 & 0 & $\begin{array}{l}\mathrm{CCC} \text { ben }(35)+\mathrm{CCO} \text { ben }(25)+ \\
\text { HCCC out }(13)\end{array}$ \\
\hline 43 & 783 & 800 & 795 & 6 & 2 & 0 & 0 & $\begin{array}{l}\text { CCC ben }(42)+\mathrm{CNN} \text { ben }(25)+ \\
\text { CS str }(16)\end{array}$ \\
\hline 44 & 752 & 751 & 764 & 5 & 1 & 51 & 2 & $\begin{array}{l}\mathrm{CCC} \text { ben }(45)+\mathrm{NCH} \text { ben }(32)+ \\
\mathrm{NCO} \text { ben }(21)\end{array}$ \\
\hline 45 & 731 & & 718 & 7 & 2 & 4 & 0 & $\begin{array}{l}\text { CCO ben }(44)+\text { CCC ben }(23)+ \\
\text { CS str }(15)\end{array}$ \\
\hline 46 & 706 & 703 & 710 & 38 & 10 & 4 & 0 & $\begin{array}{l}\text { HCCC out (42)+ NCH ben }(20)+ \\
\text { NCO ben }(21)\end{array}$ \\
\hline 47 & & & 691 & 0 & 0 & 3 & 0 & $\begin{array}{l}\text { HCCC out }(42)+\mathrm{CCC} \text { ben }(38)+ \\
\text { CC S ben }(11)\end{array}$ \\
\hline 48 & & 680 & 684 & 49 & 13 & 2 & 0 & $\begin{array}{l}\text { NCO ben }(41)+\text { CS str }(22)+ \\
\text { HCCC out }(31)\end{array}$ \\
\hline 49 & 612 & 632 & 629 & 12 & 3 & 4 & 0 & $\begin{array}{l}\text { CNN ben }(35)+\text { NNCC tor (26)+ } \\
\text { FCCC out (15) }\end{array}$ \\
\hline 50 & 604 & & 619 & 7 & 2 & 14 & 1 & $\begin{array}{l}\text { NCC ben }(60)+\text { CCF ben }(13)+ \\
\text { FCCC out }(15)\end{array}$ \\
\hline 51 & 585 & 582 & 569 & 7 & 2 & 4 & 0 & $\begin{array}{l}\mathrm{NCH} \text { ben }(50)+\mathrm{HCCS} \text { out }(24)+ \\
\mathrm{CCS} \text { ben }(17)\end{array}$ \\
\hline 52 & 540 & & 546 & 0 & 0 & 1 & 0 & $\begin{array}{l}\text { CSstr }(54)+\text { CCC ben }(24)+ \\
\text { CCS ben }(15)\end{array}$ \\
\hline 53 & 523 & & 513 & 25 & 6 & 0 & 0 & CS str(55) + HCCC out (40) \\
\hline 54 & 494 & & 478 & 41 & 11 & 10 & 0 & CCC ben (47) + NCC ben (28) \\
\hline 55 & & & 457 & 2 & 1 & 1 & 0 & $\begin{array}{l}\text { NNH ben }(38)+\text { HNNC tor }(29) \\
+ \text { CCF ben }(23)\end{array}$ \\
\hline 56 & & & 439 & 15 & 4 & 1 & 0 & HNNC tor (39) + NNCC tor (35) \\
\hline 57 & & 420 & 415 & 19 & 5 & 6 & 0 & HCNN tor $(34)+$ NNH ben $(26)$ \\
\hline 58 & & 404 & 409 & 1 & 0 & 1 & 0 & $\begin{array}{l}\text { CCS ben }(47)+\text { HNNC tor }(24)+ \\
\text { CCFstr(16) }\end{array}$ \\
\hline 59 & & & 384 & 2 & 1 & 3 & 0 & CCF ben $(63)+$ FCCC out $(30)$ \\
\hline 60 & & & 381 & 3 & 1 & 3 & 0 & HCCS out (45) + NNH ben (34) \\
\hline 61 & & & 355 & 1 & 0 & 0 & 0 & $\begin{array}{l}\text { NNCC tor }(49)+\text { CCF ben }(29)+ \\
\text { FCCC out }(12)\end{array}$ \\
\hline 62 & & 282 & 265 & 11 & 3 & 2 & 0 & $\begin{array}{l}\text { NNCC tor (38)+ NNCO tor (22) } \\
+ \text { CCC ben }(24)\end{array}$ \\
\hline 63 & & & 232 & 10 & 3 & 1 & 0 & $\begin{array}{l}\text { FCCC out (49) + CNN ben (17) + } \\
\text { CCCC out (35) }\end{array}$ \\
\hline 64 & & 223 & 218 & 0 & 0 & 3 & 0 & NNCO tor $(47)+$ CNN ben $(48)$ \\
\hline 66 & & 160 & 165 & 7 & 2 & 3 & 0 & $\begin{array}{l}\text { HNCO tor }(46)+\text { NNCO tor }(24) \\
+ \text { CNNC tor }(18)\end{array}$ \\
\hline 67 & & & 111 & 2 & 1 & 0 & 0 & $\begin{array}{l}\text { NNCO tor }(32)+\text { CCCC tor }(19) \\
+ \text { CCCO tor }(10)\end{array}$ \\
\hline 68 & & 80 & 98 & 1 & 0 & 0 & 0 & $\begin{array}{l}\text { CNNC tor }(54)+\text { NCCC tor }(26) \\
+ \text { CCCC out }(20)\end{array}$ \\
\hline 69 & & & 51 & 6 & 2 & 1 & 0 & $\begin{array}{l}\text { CCCO tor }(44)+\text { NCCC tor }(27) \\
+ \text { CCCC out }(23)\end{array}$ \\
\hline 70 & & & 41 & 1 & 0 & 0 & 0 & CCCC out (46) + NCCC tor(44) \\
\hline 71 & & & 28 & 1 & 0 & 1 & 0 & $\begin{array}{l}\text { NCCC tor }(41)+\text { CNNC tor }(30) \\
+ \text { NNCO tor }(17)\end{array}$ \\
\hline 72 & & & 22 & 1 & 0 & 2 & 0 & $\begin{array}{l}\text { NCCC tor }(40)+\text { CNNCC tor } \\
(26)+\text { CCCC out }(15)\end{array}$ \\
\hline
\end{tabular}

Abbreviations: str (stretching), ben (in-plane bending), out (out-of-plane bending), tor (torsion).

${ }^{\text {a }}$ Relative absorption intensities normalized with highest peak absorption equal to 1 .

${ }^{\mathrm{b}}$ Relative Raman intensities normalized to 100 .

c Only PED contributions $\geq 10 \%$ are listed.

\subsection{1. $C$ - $H$ vibrations}

Aromatic compounds commonly exhibit multiple weak bands in the region of $3100-3000$ $\mathrm{cm}^{-1}$ due to the aromatic $\mathrm{C}-\mathrm{H}$ stretching vibrations. They are not appreciably affected by the nature of the substituent [55-58]. In the present study, the $\mathrm{C}-\mathrm{H}$ vibrations of the title compound are observed at 
3124, 3058 and $2904 \mathrm{~cm}^{-1}$ in the FT-IR spectrum and the same type of vibrations are observed at $3101,3090,3080,3079,3050$ and $2895 \mathrm{~cm}^{-1}$ in the FT-Raman spectrum. The bands due to the in-plane $\mathrm{C}-\mathrm{H}$ bending vibrations are observed in the region of $1000-1300 \mathrm{~cm}^{-1}[59,60]$. The in-plane $\mathrm{C}-\mathrm{H}$ bending vibrations are predicted at 1270,1170 , 1130, 1102, 1077, 1161 and $1032 \mathrm{~cm}^{-1}$ by the B3LYP/6-311++G(d,p) method, which showed excellent agreement with the FT-IR bands at 1162, 1152, 1092 and $1025 \mathrm{~cm}^{-1}$ and the FT-Raman bands at 1162, 1092 and $1073 \mathrm{~cm}^{-1}$. The aromatic in-plane $\mathrm{C}-\mathrm{H}$ bending vibrations have substantial overlapping with the ring $\mathrm{C}-\mathrm{C}$ stretching vibrations. The absorption band arising from out-ofplane $\mathrm{C}-\mathrm{H}$ bending vibrations are usually observed in the region of $1000-670 \mathrm{~cm}^{-1}$. The out-of-plane C-H bending vibrations are observed at 952, 929, 879 , and $706 \mathrm{~cm}^{-1}$ in FT-IR and by the band observed at $703 \mathrm{~cm}^{-1}$ in the FT-Raman spectra. This also shows good agreement with theoretically scaled harmonic wavenumber values.

\subsubsection{Phenyl ring vibrations}

The stretching vibrations are expected within the region of $1600-1390 \mathrm{~cm}^{-1}$ [61]. In general, the bands are of variable intensity and are observed at 1625-1590, 1575-1590, 1470-1540, 1430-1465 and $1280-1380 \mathrm{~cm}^{-1}$ from the frequency ranges given by Varsanyi [58] for the five bands in the region. Most of the ring modes are altered by the substitution to the aromatic ring. The $\mathrm{C}-\mathrm{C}$ stretching vibrations in aromatic compounds usually form strong bands. In the present study, the bands are of different intensities and are observed at 1654, $1609,1512,1417,1383,1352$ and $1325 \mathrm{~cm}^{-1}$ in the FT-IR and 1612, 1588, 1513, 1504, 1414, 1392 and $1354 \mathrm{~cm}^{-1}$ in the FT-Raman, and have been assigned to the $\mathrm{C}-\mathrm{C}$ stretching vibrations. The theoretically calculated values are found at 1682 , 1610, 1579, 1560, 1510, 1497, 1474, 1404, 1386, 1336 and $1322 \mathrm{~cm}^{-1}$ by the B3LYP/6-311++G(d,p) method and these values show excellent agreement with the experimental data. The $\mathrm{C}-\mathrm{C}$ in-planebending and out-of-plane bending modes also showed good agreement with the experimental data.

\subsection{3. $C-N$ and $C$-S vibrations}

The identification of the C-N stretching frequencies in the side chain is a rather difficult task, since there are problems in distinguishing these frequencies from other vibrations. The C-N stretching usually lies in the region of $1400-1200$ $\mathrm{cm}^{-1}[62,63]$. In this study, the C-N stretching vibrations are identified at $1296,1215 \mathrm{~cm}^{-1}$ in the FT-IR and at 1294, 1250 and $1216 \mathrm{~cm}^{-1}$ in the FTRaman spectra. The assignment of the C-S stretching vibration in different compounds is difficult. Both the aliphatic and aromatic sulfides have a weak to medium band due to the C-S stretching vibration in the $570-380 \mathrm{~cm}^{-1}$ region [64]. In the present study, the band observed at $540 \mathrm{~cm}^{-1}$ in the FT-IR and $523 \mathrm{~cm}^{-1}$ in the FT-Raman spectra are assigned to the $\mathrm{C}-\mathrm{S}$ stretching vibration.

\subsection{Fukui function}

The Fukui function (FF) is one of the widely used local density functional descriptors to model chemical reactivity and selectivity. The Fukui function is a local reactivity descriptor that indicates the preferred regions where a chemical species will change its density when the number of electrons is modified. Therefore, it indicates the propensity of the electron density to deform at a given position upon accepting or donating electrons [65-67]. In addition, it is possible to define the corresponding condensed or atomic Fukui functions on the $\mathrm{j}^{\text {th }}$ atom site for an electrophilic $f_{j}^{-}(\mathrm{r})$, nucleophilic or free radical attack $f_{j}^{+}(\mathrm{r})$, respectively, on the reference molecule as:

$$
\begin{gathered}
f_{j}^{-}=q_{j}(\mathrm{~N})-q_{j}(\mathrm{~N}-1) \\
f_{j}^{+}=q_{j}(\mathrm{~N}+1)-q_{j}(\mathrm{~N}) \\
f_{j}^{0}=\frac{1}{2}\left[q_{j}(\mathrm{~N}+1)-q_{j}(\mathrm{~N}-1)\right]
\end{gathered}
$$

In these equations, $q_{j}$ is the atomic charge (evaluated from Mülliken population analysis, electrostatic derived charge, etc.) at the $\mathrm{j}^{\text {th }}$ atomic site in the neutral $(\mathrm{N})$, anionic $(\mathrm{N}+1)$ or cationic (N-1) chemical species. Chattaraj et al. [68], have introduced the concept of generalized philicity. It contains almost all information about hitherto known different global and local reactivity and selectivity descriptors, in addition to the information regarding electrophilic/nucleophilic power of a given atomic site in a molecule. Morell et al. [69] have recently proposed a dual descriptor $(\Delta f$ $(\mathrm{r})$ ), which is defined as the difference between the nucleophilic and electrophilic Fukui function and is given by:

$$
\Delta f_{\mathrm{k}}(\mathrm{r})=\left[f_{\mathrm{j}}^{+}(\mathrm{r})-f_{\mathrm{j}}^{-}(\mathrm{r})\right] .
$$

If $\Delta f(\mathrm{r})>0$, the site is favored for a nucleophilic attack, whereas, if $\Delta f(\mathrm{r})<0$, the site may be favored for an electrophilic attack. In this situation, 
the dual descriptors $\Delta f(\mathrm{r})$ provide a clear difference between the nucleophilic and electrophilic attack at a particular site with their sign. That is, they provide a positive value for sites prone to nucleophilic attack and a negative value for sites prone to electrophilic attack. From the values reported in Table 6 , according to the dual descriptor conditions, the nucleophilic site for the title compound is $\mathrm{C}_{3}, \mathrm{~S}_{5}, \mathrm{C}_{6}, \mathrm{C}_{10}, \mathrm{C}_{12}, \mathrm{C}_{14}, \mathrm{C}_{15}, \mathrm{H}_{21}, \mathrm{H}_{22}$ (positive value i.e. $\Delta \mathrm{f}(\mathrm{r})>0)$. Similarly, the electrophilic attack site is $\mathrm{C}_{1}, \mathrm{C}_{2}, \mathrm{C}_{4}, \mathrm{O}_{7}, \mathrm{~N}_{8}, \mathrm{~N}_{9}, \mathrm{C}_{11}, \mathrm{C}_{13}, \mathrm{C}_{16}, \mathrm{C}_{17}, \mathrm{H}_{18}, \mathrm{H}_{19}, \mathrm{H}_{20}, \mathrm{H}_{23}$, $\mathrm{H}_{24}, \mathrm{H}_{25}, \mathrm{H}_{26}$ (negative value i.e $\Delta f(\mathrm{r})<0$ ). The behavior of molecules as electrophiles/nucleophiles during a reaction depends on the local behavior of molecules.

\section{Table 6}

Values of the Fukui function considering Mulliken charges according with equations (1-3)

\begin{tabular}{cccc}
\hline \hline Atoms & $\boldsymbol{f}_{\mathbf{j}}^{-}$ & $\boldsymbol{f}_{\mathbf{j}}^{+}$ & $\boldsymbol{\Delta} \boldsymbol{f}_{\mathbf{k}}$ \\
\hline $\mathrm{C}_{1}$ & 0.4317 & -0.4597 & -0.8914 \\
$\mathrm{C}_{2}$ & 0.5648 & -0.6116 & -1.1764 \\
$\mathrm{C}_{3}$ & -0.5273 & 0.4915 & 1.0188 \\
$\mathrm{C}_{4}$ & 0.2959 & -0.3962 & -0.6922 \\
$\mathrm{~S}_{5}$ & -0.6226 & 0.3979 & 1.0206 \\
$\mathrm{C}_{6}$ & -0.8188 & 0.7778 & 1.5966 \\
$\mathrm{O}_{7}$ & 0.0976 & -0.2217 & -0.3193 \\
$\mathrm{~N}_{8}$ & 0.2083 & -0.2668 & -0.4751 \\
$\mathrm{~N}_{9}$ & 0.4384 & -0.5336 & -0.9719 \\
$\mathrm{C}_{10}$ & -0.9026 & 0.8116 & 1.7141 \\
$\mathrm{C}_{11}$ & 1.0677 & -1.0583 & -2.1260 \\
$\mathrm{C}_{12}$ & -1.1044 & 1.0704 & 2.1748 \\
$\mathrm{C}_{13}$ & 0.3250 & -0.3504 & -0.6754 \\
$\mathrm{C}_{14}$ & -0.7466 & 0.6584 & 1.4050 \\
$\mathrm{C}_{15}$ & -0.1390 & 0.1183 & 0.2572 \\
$\mathrm{C}_{16}$ & 0.4168 & -0.4569 & -0.8737 \\
$\mathrm{~F}_{17}$ & 0.0458 & -0.1173 & -0.1631 \\
$\mathrm{H}_{18}$ & -0.0341 & -0.0697 & -0.0356 \\
$\mathrm{H}_{19}$ & -0.0247 & -0.1055 & -0.0808 \\
$\mathrm{H}_{20}$ & -0.0530 & -0.0756 & -0.0226 \\
$\mathrm{H}_{21}$ & -0.1031 & 0.0255 & 0.1285 \\
$\mathrm{H}_{22}$ & -0.0691 & -0.0469 & 0.0223 \\
$\mathrm{H}_{23}$ & -0.0135 & -0.0618 & -0.0483 \\
$\mathrm{H}_{24}$ & -0.0186 & -0.0816 & -0.0630 \\
$\mathrm{H}_{25}$ & -0.0153 & -0.0807 & -0.0654 \\
$\mathrm{H}_{26}$ & 0.4519 & -0.5085 & -0.9604 \\
\hline \hline & & & \\
\hline
\end{tabular}

\section{CONCLUSIONS}

The FT-IR and FT-Raman spectra were recorded and the detailed vibrational assignments were presented using the DFT method with the 6$311++\mathrm{G}(\mathrm{d}, \mathrm{p})$ basis set for the title compound. The theoretically-constructed FT-IR and FT-Raman spectra show good correlation with experimentally-observed spectra. The thermodynamic properties in the range of 100 to $1000 \mathrm{~K}$ were obtained.
The gradients of $\mathrm{C}, \mathrm{S}$ and $\mathrm{H}$ increased as the temperature increased. The value of $\beta$ and $\mu$ suggest the possibility of technological (NLO) applications. The strong intramolecular hyperconjugative interaction of the $\sigma$ and $\pi$ electrons to the C-C antibond of the ring leads to stabilization of the ring as confirmed by NBO analysis. The difference in the HOMO and LUMO energies support the charge transfer interaction within the molecule. The MEP map shows the negative potential sites on $\mathrm{N}, \mathrm{O}, \mathrm{S}$ and $\mathrm{F}$ atoms and the positive potential sites around the $\mathrm{H}$ atoms.

Acknowledgment. The authors would like to extend their appreciation to the Deanship of Scientific Research at King Saud University for funding this study through the research group project No. PRG-1436-23.

\section{REFERENCES}

[1] H. H. Fox, Synthetic tuberculstats. I. Pyridine carboxylic acid derivatives, J. Org. Chem. 17, 542-546 (1952).

[2] H. H. Fox, J. T. Gibas, Synthetic tuberculstats. IX. Dialkyl derivatives of isonicotinylhydrazine, $J$. Org. Chem. 20, 60-69 (1955).

[3] A. Manvar, A. Bavishi, A. Radadiya, J. Patel, V. Vora, N. Dodia, K. Rawal, A. Shah, Diversity oriented design of various hydrazides and their in vitro evaluation against Mycobacterium tuberculosis $\mathrm{H}_{3} 7_{\mathrm{Rv}}$ strains, Bioorg. Med. Chem. Lett. 21, 4728-4731 (2011).

[4] A. Manvar, A. Malde, J. Verma, V. Virsodia, A. Mishra, K. Upadhyay, H. Acharya, E. Coutinho, A. Shah, Synthesis, anti-tubercular activity and 3D-QSAR study of coumarin-4-acetic acid benzylidene hydrazides, Eur. J. Med. Chem. 43, 23952403 (2008).

[5] R. Maccari, R. Ottanà, M. G. Vigorita, In vitro advanced antimycobacterial screening of isoniazidrelated hydrazones, hydrazides and cyanoboranes: Part 14, Bioorg. Med. Chem. Lett. 15, 2509-2513 (2005).

[6] P. Kumar, B. Narasimhan, P. Yogeeswari, D. Sriram, Synthesis and antitubercular activities of substituted benzoic acid $N^{\prime}$-(substituted benzylidene/furan-2-ylmethylene)- $N$-(pyridine-3-carbonyl)-hydrazides, Eur. J. Med. Chem. 45, 60856089 (2010).

[7] F. Martins, S. Santos, C. Ventura, R. Elvas-Leitão, L. Santos, S. Vitorino, M. Reis, V. Miranda, H. F. Correia, J. Aires-de-Sousa, V. Kovalishyn, D. A. R. S. Latino, J. Ramos, M. Viveiros, Design, synthesis and biological evaluation of novel isoniazid derivatives with potent antitubercular activity, Eur. J. Med. Chem. 81, 119-138 (2014). 
[8] A. Özdemir, G. Turan-Zitouni, Z. A. Kaplancikli, Y. Tunali, Synthesis and biological activities of new hydrazide derivatives, J. Enzyme Inhib. Med. Chem. 24, 825-831 (2009).

[9] G. L. Backes, D. M. Neumann, B. S. Jursic, Synthesis and antifungal activity of substituted salicylaldehyde hydrazones, hydrazides and sulfohydrazides, Bioorg. Med. Chem. 22, 4629-4636 (2014)

[10] P. Vicini, F. Zani, P. Cozzini, I. Doytchinova, Hydrazones of 1,2-benzisothiazole hydrazides: Synthesis, antimicrobial activity and QSAR investigations, Eur. J. Med. Chem. 37, 553-564 (2001).

[11] K. A. Metwally, L. M. Abdel-Aziz, E. S. Lashine, M. I. Husseiny, R. H. Badawy, Hydrazones of 2aryl-quinoline-4-carboxylic acid hydrazides: Synthesis and preliminary evaluation as antimicrobial agents, Bioorg. Med. Chem. 14, 8675-8682 (2006)

[12] G. Turan-Zitouni, M.D. Altıntop, A. Özdemir, F. Demirci, U. Abu Mohsen, Z. A. Kaplanciklı, Synthesis and antifungal activity of new hydrazide derivatives, J. Enzyme Inhib. Med. Chem. 28, 12111216 (2013).

[13] Z. Garkani-Nejad, B. Ahmadi-Roudi, Modeling the antileishmanial activity screening of 5-nitro-2heterocyclic benzylidene hydrazides using different. chemometrics methods, Eur. J. Med. Chem. 45, 719-726 (2010).

[14] K. M. Khan, M. Rasheed, Z. Ullah, S. Hayat, F. Kaukab, M. I. Choudhary, Atta ur-Rahman, S. Perveen, Synthesis and in vitro leishmanicidal activity of some hydrazides and their analogues, Bioorg. Med. Chem. 11, 1381-1387 (2003).

[15] D. Kumar, V. Judge, R. Narang, S. Sangwan, E. De Clercq, J. Balzarini, B. Narasimhan, Benzylidene/2-chlorobenzylidene hydrazides: Synthesis, antimicrobial activity, QSAR studies and antiviral evaluation, Eur. J. Med. Chem. 45, 2806-2816 (2010).

[16] H. -Z. Zhang, J. Drewe, B. Tseng, S. Kasibhatla, S. $X$. Cai, Discovery and SAR of indole-2-carboxylic acid benzylidene-hydrazides as a new series of potent apoptosis inducers using a cell-based HTS assay, Bioorg. Med. Chem. 12, 3649-3655 (2004).

[17] S. S. Machakanur, B. R. Patil, D. S. Badiger, R. P. Bakale, K. B. Gudasi, S. W. Annie Bligh, Synthesis, characterization and anticancer evaluation of novel tri-arm star shaped 1,3,5-triazine hydrazones, J. Mol. Struct. 1011, 121-127 (2012).

[18] W. Liao, C. Xu, X. Ji, G. Hu, L. Ren, Y. Liu, R. Li, P. Gong, T. Sun, Design and optimization of novel 4-(2-fluorophenoxy)quinoline derivatives bearing a hydrazine moiety as c-Met kinase inhibitors, Eur. J. Med. Chem. 87, 508-518 (2014).
[19] C. M. Moldovan, O. Oniga, A. Pârvu, B. Tiperciuc, P. Verite, A. Pîrnău, O. Crişan, M. Bojiţă, R. Pop, Synthesis and anti-inflammatory evaluation of some new acyl-hydrazones bearing 2-aryl-thiazole, Eur. J. Med. Chem. 46, 52-534 (2011).

[20] D. Hadjipavlou-Litina, A. Samadi, M. Unzeta, J. Marco-Contelles, Analysis of the antioxidant properties of differently substituted 2- and 3-indolyl carbohydrazides and related derivatives, Eur. $J$. Med. Chem. 63, 670-674 (2013).

[21] S. G. Küçükgüzel, A. Kocatepe, E. De Clercq, F. Şahin, M. Güllüce, Synthesis and biological activity of 4-thiazolidinones, thiosemicarbazides derived from diflunisal hydrazide, Eur. J. Med. Chem. 41, 353-359 (2006).

[22] S. J. Gilani, S. A. Khan, O. Alam, V. Singh, A. Arora, Thiazolidin-4-one, azetidin-2-one and 1,3, 4-oxadiazole derivatives of isonicotinic acid hydrazide: synthesis and their biological evaluation, J. Serb. Chem. Soc. 76, 1057-1067 (2011).

[23] K. Ilango, S. Arunkumar, Synthesis, antimicrobial and antitubercular activities of some novel trihydroxy benzamido azetidin-2-one derivatives, Trop . J. Pharm. Res. 10, 219-229 (2011).

[24] M. Ishii, S. D. Jorge, A. A. de Oliveira, F. PalaceBerl, I. Y. Sonehara, K. F. M. Pasqualoto, L.C. Tavares, Synthesis, molecular modeling and preliminary biological evaluation of a set of 3-acetyl2,5-disubstituted-2,3-dihydro-1,3,4-oxadiazole as potential antibacterial, anti-Trypanosoma cruzi and antifungal agents, Bioorg. Med. Chem. 19, 62926301 (2011)

[25] H. Hamdi, V. Passarelli, A. Romerosa, Synthesis, spectroscopy and electrochemistry of new 4-(4acetyl-5-substituted-4,5-dihydro-1,3,4-oxodiazol2-yl)methoxy)-2H-chromen-2-ones as a novel class of potential antibacterial and antioxidant derivatives, Compt. Rend. Chim. 14, 548-555 (2011).

[26] G. S. Hassan, A. A. El-Emam, M. L. Gad, A. M. Barghash, Synthesis, antimicrobial and antiviral testing of some new 1-adamantyl analogues, Saudi Pharm. J. 18, 123-128 (2010).

[27] G. V. S. Kumar, Y. Rajendraprasad, B. P. Mallikarjuna, S. M. Chandrashekar, C. Kistayya, Synthesis of some novel 2-substituted-5-[isopropylthiazole] clubbed 1,2,4-triazole and 1,3,4-oxadiazoles as potential antimicrobial and antitubercular agents, Eur. J. Med. Chem. 45, 2063-2074 (2010).

[28] A. A. El-Emam, K. A. Alrashood, M. A. Al-Omar, A. -M. S. Al-Tamimi, Synthesis and antimicrobial activity of $N^{\prime}$-heteroarylidene-1-adamantylcarbohydrazides and ( \pm )-2-(1-adamantyl)-4-acetyl-5-[5(4-substituted phenyl-3-isoxazolyl)]-1,3,4-oxadiazolines, Molecules 17, 3475-3483 (2012). 
[29] R. Mishra, R. Kumar, S. Kumar, J. Majeed, M. Rashid, S. Sharma, Synthesis and in vitro antimicrobial activity of some triazole derivatives, $J$. Chil. Chem. Soc. 55, 359-362 (2010).

[30] A. M. Alanazi, S. Lahsasni, A. A. El-Emam, S. W. $\mathrm{Ng}, \quad N^{\prime}$-[(1E)-(4-fluorophenyl)methylidene]-thiophene-2-carbohydrazide. Acta Cryst. E68, o314 (2012).

[31] H. B. Schlegel, Optimization of equilibrium geometries and transition structures, J. Comput. Chem. 3, 214-218 (1982).

[32] Gaussian 03 Program, Gaussian Inc., Wallingford, CT (2004).

[33] M. Govindarajan, M. Karabacak, S. Periandy, D. Tanuja, Spectroscopic (FT-IR, FT-Raman, UV and NMR) investigation and NLO, HOMO-LUMO, NBO analysis of organic 2,4,5-trichloroaniline, Spectrochim. Acta A 97, 231-245 (2012).

[34] J. B. Foresman, A. Frisch, Exploring Chemistry with Electronic Structure Methods, Gaussian Inc., Pittsburgh, 1996.

[35] G. Keresztury, S. Holly, J. Varga, G. Bensenyei, A. Y. Wang, J. R. Durig, Vibrational spectra of monothiocarbamates II. IR and Raman spectra, vibrational assignment, conformational analysis and $a b$ initio calculations of $S$-methyl- $N, N$-dimethylthiocarbamate, Spectrochim. Acta A 49, $2007-$ 2017 (1993).

[36] G. Fogarasi, P. Pulay (J. R. Durig, Ed.), Vibrational Spectra and Structure, Vol. 14, Elsevier, Amsterdam (1985).

[37] S. Muthu, E. E. Porchelvi, M. Karabacak, A. M. Asiri, S. S. Swathi, Synthesis, structure, spectroscopic studies (FT-IR, FT-Raman and UV), normal coordinate, NBO and NLO analysis of salicylaldehyde p-chlorophenylthiosemicarbazone, $J$. Mol. Struct. 1081, 400-412 (2015).

[38] J. P. Hermann, D. Ricard, J. Ducuing, Optical nonlinearities in conjugated systems: $\beta$-carotene, Appl. Phys. Lett. 23, 178-180 (1973).

[39] A. Ben Ahmed, H. Feki, Y. Abid, H. Boughzala, C. Minot, A. Mlayah, Crystal structure, vibrational spectra and theoretical studies of L-histidinium dihydrogen phosphate-phosphoric acid, J. Mol. Struct. 920, 1-7 (2009).

[40] V. Karunakaran, V. Balachandran, FT-IR, FTRaman spectra, NBO, HOMO-LUMO and thermodynamic functions of 4-chloro-3-nitrobenzaldehyde based on $a b$ initio HF and DFT calculations, Spectrochim. Acta A 98, 229-239 (2012).

[41] N. R. Sheela, S. Muthu, S. Sampathkrishnan, A. A. Al-Saadi, Normal co-ordinate analysis, molecular structural, non-linear optical, second order perturbation studies of tizanidine by density functional theory, Spectrochim. Acta A 139, 189-199 (2015).
[42] C. James, A. A. Raj, R. Reghunathan, V. S. Jayakumar, I. H. Joe, Structural conformation and vibrational spectroscopic studies of 2,6-bis $(p-N, N$ dimethyl benzylidene)cyclohexanone using density functional theory, J. Raman Spectrosc. 37, 13811392 (2006).

[43] Y. Ataly, D. Avci, A. Başoğlu, Linear and nonlinear optical properties of some donor-acceptor oxadiazoles by ab initio Hartree-Fock calculations, Struct. Chem. 19, 239-246 (2008).

[44] T. Vijayakumar, I. H. Joe, C. P. R. Nair, V. S. Jayakumar, Efficient $\pi$ electrons delocalization in prospective push-pull non-linear optical chromophore 4-[N,N-dimethylamino]-4'-nitro stilbene (DANS): A vibrational spectroscopic study, Chem. Phys. 343, 83-99 (2008).

[45] S. Muthu, S. Renuga, Vibrational spectra and normal coordinate analysis of 2-hydroxy-3-(2-methoxyphenoxy)propyl carbamate, Spectrachim. Acta A 132, 313-325 (2014).

[46] K. Fukui, Theory of Orientation and Stereo Selection, Springer Verlag, Berlin, 1975.

[47] D. F. V. Lewis, C. loannides, D. V. Parke, Interaction of a series of nitriles with the alcoholinducible isoform of P450: Computer analysis of structure-activity relationships, Xenobiotica 24, 401-408 (1994).

[48] R. Hoffmann, Solids and Surfaces: A chemist's view of bonding in extended structures, VCH Publishers, New York, 1988.

[49] J. U. Maheswari, S. Muthu, T. Sundiu, QM/MM methodology, docking and spectroscopic (FTIR/FT-Raman NMR, UV) and Fukui function analysis on adrenergic agonist, Spectrochim. Acta A 137, 841-855 (2015).

[50] N. M. O’Boyle, A. L. Tenderholt, K. M. Langner, CCLIB: a library for package-independent computational chemistry algorithms, J. Comput. Chem. 29, 839-845 (2008).

[51] K. Bhavani, S. Renuga, S. Muthu, K. Sankaranarayanan, Quantum mechanical study and spectroscopic (FT-IR, FT-Raman, ${ }^{13} \mathrm{C},{ }^{1} \mathrm{H}$ study, first order hyperpolarizability, NBO analysis, HOMO and LUMO analysis of 2-acetoxybenzoic acid by density functional methods, Spectrochim. Acta A 136, 1260-1268 (2015).

[52] R. Shahidha, S. Muthu, E. M. Porchelvi, M. Govindarajan, Normal coordinate analysis and vibrational spectroscopy (FT-IR and FT-Raman) studies of 5-methyl- $\mathrm{N}$-[4-(trifluoromethyl) phenyl]-isoxazole-4-carboxamide using density functional method, Spectrochim. Acta A 132, 142-151 (2014).

[53] M. Silverstein, G. C. Bassler, C. Morril, Spectroscopic Identification of Organic Compounds, Fifth ed., John Wiley \& Sons Inc., Singapore, 1991. 
[54] E. B. Wilson, J. C. Decius, P. C. Cross, Molecular Vibrations, Dover Publications Inc., New York, 1980.

[55] G. Socrates, Infrared and Raman Characteristic Group Frequencies. Tables and charts. Third ed., John Wiley, New York 2001.

[56] N. B. Colthup, L. H. Daly, S. E. Wiberley, Introduction to Infrared and Raman Spectroscopy, Academic Press, New York, 1990.

[57] F. R. Dollish, W. G. Fateley, F. F. Benteley, Characteristic Raman Frequencies of Organic Compounds, Wiley, New York (1997).

[58] G. Varasanyi, Vibrational Spectra of Benzene Derivatives, Academic Press, New York, 1969.

[59] M. H. Jamróz, J. Cz. Dobrowolski, R. Brzozowski, Vibrational modes of 2,6-, 2,7-, and 2,3-diisopropylnaphthalene. A DFT study, J. Mol. Struct. 787, 172-183 (2006).

[60] S. Muthu, A. Prabhakaran, Vibrational spectroscopic study and NBO analysis on tranexamic acid using DFT method, Spectrochim. Acta A 129, 184192 (2014).

[61] V. S. Madhavana, H. T. Vargheseb, S. Mathewc, J. Vinsovad, C. Y. Panicker, FT-IR, FT-Raman and DFT calculations of 4-chloro-2-(3,4-dichlorophenylcarbamoyl)phenyl acetate, Spectrochim. Acta A 72, 547-553 (2009).

[62] M. Arivazhagan, V. Krinshnakumar, R. J. Xavier, G. Elango, V. Balachandran, FT-IR, FT-Raman, scaled quantum chemical studies of the structure and vibrational spectra of 1,5-dinitronaphthalene, Spectrachim. Acta A 72, 941-946 (2009).
[63] A. Atac, M. Karabacak, C. Karacaa, E. Kose, NMR, UV, FT-IR, FT-Raman spectra and molecular structure (monomeric and dimeric structures) investigation of nicotinic acid $N$-oxide: A combined experimental and theoretical study, Spectrochim. Acta A 85, 145-154 (2012).

[64] E. E. Porchelvi, S. Muthu, Vibrational spectra, molecular structure, natural bond orbital, first order hyperpolarizability, thermodynamic analysis and normal coordinate analysis of salicylaldehyde p-methylphenylthiosemicarbazone by density functional method, Spectrochim. Acta A 134, 453-464 (2015).

[65] R. G. Parr, W. Yang, Functional Theory of Atoms and Molecules, Oxford University Press, New York, 1989.

[66] P. W. Ayers, R. G. Parr, Variational principals for describing chemical reactions: The Fukui function and chemical hardness revisted, J. Am. Chem. Soc. 122, 2010-2018 (2000).

[67] S. Renuga, M. Karthikesan, S. Muthu, FTIR and Raman spectra, electronic spectra and normal coordinate analysis of $N, N$-dimethyl-3-phenyl-3pyridin-2-yl-propan-1-amine by DFT method, Spectrochim. Acta A 127, 439-453 (2014).

[68] P. K. Chattaraj, B. Maiti, U. Sarkar, Philicity: A unified treatment of chemical reactivity and selectivity, J. Phys. Chem. A 107, 4973-4975 (2003).

[69] C. Morell, A. Grand, A. Toro-Labbe, New dual descriptor for chemical reactivity, J. Phys. Chem. A 109, 205-212 (2005). 
